\title{
Causal Relationships between Economic Policy Uncertainty and Housing Market Returns in China and India: Evidence from Linear and Nonlinear Panel and Time Series Models ${ }^{\#}$
}

\author{
Sheung-Chi Chow
}

Research Institute for Business, Hang Seng Management College

\author{
Juncal Cunado*
}

Facultad de Ciencias Economicas y Empresariales

Universidad de Navarra

Rangan Gupta

Department of Economics, University of Pretoria

\author{
Wing-Keung Wong** \\ Department of Finance, Asia University \\ Department of Economics, Lingnan University
}

\footnotetext{
\# We would like to thank two anonymous referees for many helpful comments. However, any remaining errors are solely ours.

* Juncal Cunado gratefully acknowledges financial support from the Ministerio de Economía y Competitividad (ECO2014-55496-R).

** The fourth author would like to thank Robert B. Miller and Howard E. Thompson for their continuous guidance and encouragement. This research has been partially supported by grants of Hang Seng Management College, University of Pretoria, Asia University, Lingnan University, and the Research Grants Council (RGC) of Hong Kong (project numbers UGC/IDS14/15, 12500915 and 134036).
} 


\begin{abstract}
In this paper, we modify the multivariate nonlinear causality test to be panel nonlinear causality test and we apply these and other existing related tests to examine the causal relationship between Economic Policy Uncertainty (EPU) and real housing returns in China and India using quarterly data from 2003:01 to 2012:04. Both panel linear and nonlinear Granger causality tests suggest the existence of only linear and nonlinear unidirectional causality relationships from changes in EPU to real housing returns in both China and India, and bivariate linear Granger causality tests suggest the existence of only linear unidirectional causality relationship from changes in EPU to real housing returns only in China. However, nonlinear bivariate Granger causality tests conclude the existence of nonlinear bidirectional causality relationships between changes in EPU and real housing returns in both China and India and cross bivariate linear and nonlinear Granger causality tests discover that there is only a linear causality relationship from Indian changes in EPU to Chinese housing returns. The results confirm the relevance of EPU data to better understand and predict the future behaviour of housing market returns in these countries.
\end{abstract}

Keywords: Economic policy uncertainty; Housing market returns; Granger causality linear and nonlinear tests.

JEL classification: C32; G10; R30. 


\section{Introduction}

China and India are the world's most important emerging economies, they represent $16 \%$ of world GDP, and, according to the Global Competitiveness Report 2015, they are the second and third biggest economies according to their market size. Because of these two countries' relevance to international markets, and coinciding with a moment of high uncertainty, a lot of attention has been paid to their economic situation by international investors, policymakers and international institutions. Furthermore, the real estate market is one of the most important sectors in many economies, including China and India. It represents the second largest employer after agriculture in India, it is expected to grow at a 30 percent rate over the next decade in this country, and the construction industry in this country ranks third among the 14 major sectors in terms of direct, indirect and induced effects in all sectors of the economy. Real estate has also been a key engine of China's rapid growth during the last decade, increasing from a 4 percent of GDP in 1997 to a 15 percent of GDP in 2014. Furthermore, it has strong linkages to several industries and the growth contribution of real estate investment is estimated to be more than 10 percent in this country. Moreover, the high growth rates of the construction sector in China are behind this country's consumption of commodities, mainly energy and metals ${ }^{1}$, and the general increase in commodity prices (World Bank, 2015). In addition, the collapse of some housing bubbles has been followed by global crisis, as in the case of Japan (after house prices rose by about 40 percent during the mid-80s, the end of the housing bubble was followed by a "lost decade" of no income growth) or the United States (after huge house prices increases between 2001 and 2006, the end of the housing bubble was followed by the global financial crisis). All these reasons motivate the analysis of real housing returns in these two countries in a period

\footnotetext{
${ }^{1}$ According to the World Bank, China's consumption of metals and coal surged to roughly $50 \%$ of world consumption in this period.
} 
of high policy uncertainty. Although both countries, China and India, have experienced over the last decades a large population growth, one key factor influencing the growth in residential investment, the paths of residential construction have been different in each of these countries, due to several factors, such as the urbanisation and average per capita income growth. In China, the declining average household size, rapid urbanisation and strong income growth (compared to India) explain the rapid growth in residential investment. In contrast, slower urbanisation, lower income growth and administrative difficulties with undertaking housing development in India are behind the lower growth in residential investment in this country (D'Arcy and Veroude, 2014). Furthermore, housing finance market in India is less developed than those of other countries, including China. For example, while the amount of housing finance accounts for less than $8 \%$ of GDP in India, this percentage is equal to $12 \%$ in China, and $80 \%$ in the US (Singh et al., 2014).

Moreover, and in the wake of the 2008-09 financial crisis, economic policy uncertainty has raised a lot of attention because of its potential negative effects on many macroeconomic variables (Bloom et al., 2007; Bloom, 2009; Antonakakis et al., 2013; Pastor and Veronesi, 2012, 2013; Aasveit et al., 2013; Shoag and Veuger, 2013; Baker et al., 2015; Brogaard and Detzel, 2015; Gulen and Ion, 2015). As an example, the International Monetary Fund $(2012,2013)$ have suggested that uncertainty about US and European fiscal, regulatory, and monetary policies has contributed to the economic decline in 2008-2009. Furthermore, many authors, such as Baker et al. (2015) have obtained that the high levels of policy uncertainty are behind the weak recoveries after the financial crisis. Kang and Ratti (2015), Chen et al. (2016), Yin and Han (2014) and Li et al. (2015) have also found that economic policy uncertainty has had a negative impact on the Chinese and Indian stock market returns. 
The economic literature points to different channels through which uncertainty might negatively affect economic growth. Considering the demand side of the economy, firms will reduce investment demand and delay projects when they face a highly uncertain environment (Bernanke, 1983; McDonald and Siegel, 1986; Dixit and Pindyck, 1994; Calcagnini and Saltari, 2000), while households will reduce their consumption of durable goods (Carroll, 1996), including housing market investments (Iacoviello and Neri, 2010; Mian and Sufi, 2011; Su et al., 2016). Policy uncertainty could also increase the equity premium, and thus, the costs of financing real estate investments (Pastor and Veronesi, 2012; Brogaard and Detzel, 2015). When considering the supply side, firms' hiring plans will be also negatively affected by high uncertainty levels (Bloom, 2009). Policy uncertainty is also believed to have these potential effects on different macroeconomic variables (Friedman, 1968; Pastor and Veronesi, 2012, 2013; Fernández-Villaverde et al., 2015), and thus, housing market returns (Leamer, 2007; Nyakabawo et al, 2015). Theoretical models that support the relationship between policy uncertainty and real estate market returns, and thus, the empirical analysis carried out in this paper, can be found in Pastor and VeronesiVeronesi $(2012,2013)$ and Su et al. (2016).

Furthermore, economic literature finds both linear and non-linear relationships between policy uncertainty and economic activity variables (Nodari, 2014; Zhang et al., 2016; Ajmi et al., 2014; Caggiano et al., 2014, 2017). Nodari (2014) and Caggiano et al. (2014, 2017), for example, find that the real effects of economic policy uncertainty on unemployment rate are larger in recessions than in expansions, suggesting a non-linear relationship between EPU and unemployment rates. A nonlinear effect of EPU changes on economic activity will likely mean that a nonlinear relationship could exist between EPU changes and housing market returns. Based on this literature, in this paper we 
analyse the existence of both a linear and a non-linear relationship between EPU and housing market returns.

Among the different measures of policy uncertainty, the economic policy uncertainty index based on newspaper coverage frequency proposed by Baker et al. (2015) has become a benchmark ${ }^{2}$ for measuring economic policy uncertainty (Sum, 2012a, 2012b; Antonakakis et al., 2013, 2015, 2016; Gulen and Ion, 2015). ${ }^{3}$ In China, for example, the policy uncertainty index spikes with the township and village enterprises bankruptcy in 1995-96, the privatization and restructuring in 1997-2000, the global downturn in 2001, the global financial crisis in 2008-2009, and the euro crisis in 2010. The Chinese index reaches its peak when Xi-Li Administration began with legislation aimed at corruption and poverty in 2011 (Kang and Ratti, 2015). As far as the Indian economy is concerned, the policy uncertainty index spikes with the Iraq invasion in 2003, when the Congress Party wins the National Election in 2004, with the collapse of Lehman Brothers in 2008, with the euro crisis and the US debt ceiling debate, and with the Rupee collapse and exchange rate concerns in 2012 (Baker et al., 2015).

The impact of policy uncertainty on housing market returns has already been studied in the literature (Miller and Peng, 2006; Miles, 2008; Barros et al., 2015, Antonakakis et al., 2015; Guirguis et al., 2015; Antonakakis and Floros, 2016; Su et al., 2016; El Montasser et al, forthcoming), although most of the studies consider the case of developed countries. In this context, the objective of this paper is to analyse the bivariate causal relationship between Economic Policy Uncertainty (EPU) and real

\footnotetext{
${ }^{2}$ As an example of the great number of papers that have used this data, see the web page http://www.policyuncertainty.com/research.html.

${ }^{3}$ Alternative measures of policy uncertainty can be found in Mumtaz and Zanetti (2013), Mumtaz and Surico (2013), Mumtaz and Theodoridis (2015), Carriero et al., (2015) Jurado et al., (2015), Ludvigson et al., (2015) and Rossi and Sekhposyan (2015), among others. See Strobel (2015) for a review of alternative approaches to measure uncertainty.
} 
housing returns in China and India using quarterly data from 2003:01 to 2012:04, using both panel and bivariate linear and nonlinear Granger causality tests. Note that, since Granger causal relationships are traditionally based on vector autoregressive model, our analysis is purely a theoretical and does not involve a structural approach. To the best of our knowledge, this is the first paper to use panel bivariate linear and nonlinear causality tests to analyse the existence of a causality relationship between economic policy uncertainty and housing market returns in China and India. Hence, this study will allow us to determine to what extent EPU indices could help in predicting the real housing returns in these two economies. In addition, our study also deviates from the existing time series works, which primarily look at the G7 or OECD countries. More importantly, since our sample period covers the global financial crisis, which actually originated from the housing market, the usage of the nonlinear causality tests are of paramount importance. This is because, unlike the linear tests, the nonparametric approach adopted in the paper is data-driven and hence can capture the true nature of the relationship between housing returns and uncertainty, and would not be misspecified like the linear model, if in fact these two variables are related nonlinearly, and more importantly, if regime changes (structural breaks) had occurred due to the global financial crisis in the relationship between these two variables. Note that, nonlinear relationship is likely since increase and decrease of uncertainty (house prices) is likely to affect the housing market (uncertainty) differently, since increases (decreases) in uncertainty is generally supposed to be negative (positive) news, while increases (decreases) in real house price (if not a bubble) is viewed as positive (negative) news as it will lead to growth in consumption through the wealth effect. It is quite widely accepted that negative news tend to have bigger impact on the economy than positive news (Hatemi-J, 2012). 
The remainder of the paper is structured as follows. Section 2 discusses the methodology used in the paper. Section 3 describes the data and shows the empirical analysis. Section 4 summarizes the main findings.

\section{Data and Methodology}

\subsection{Data}

Our analysis comprises of two variables, namely, the housing market real returns and the EPU indices. We look at the two largest emerging economies, China and India, over the quarterly period of 2003:01 to 2012:04, with the start and end dates being purely driven by data availability of the EPU and house price variables respectively. The data on real housing prices are obtained from the house price database created by CesaBianchi et al. (2015), and are available for download from: https://sites.google.com/site/ambropo/publications. The data on the EPU indices for both countries are obtained from www.policyuncertainty.com, and are based on the work of Baker et al. (2015). The news-based Indian EPU index includes seven Indian newspapers: The Economic Times, the Times of India, the Hindustan Times, the Hindu, the Statesman, the Indian Express, and the Financial Express. For each paper, Baker et al. (2015) count the number of articles in newspapers containing at least one term from three term sets. The first set includes uncertain, uncertainties, or uncertainty. The second set contains economic or economy. The third set consists of policy relevant terms such as 'regulation', 'central bank', 'monetary policy', 'policymakers', 'deficit', 'legislation', and 'fiscal policy'. To measure economic policy uncertainty for China, Baker et al. (2015) construct a scaled frequency count of articles about policy-related economic uncertainty in the South China Morning Post (SCMP), the Hong Kong's most 
leading English-language newspaper. In other words, the method follows the newsbased indices of economic policy uncertainty for India and China as described above. Note that the EPU data is available at a monthly frequency, but since the house price data is quarterly, we create quarterly values of the EPU index by averaging its values over three months comprising a specific quarter - a standard practice in the EPU literature (see for example, Christou et al., forthcoming).

\subsection{Panel linear Granger causality test}

Consider I panels $\mathrm{i}=1, \ldots, \mathrm{I}$ and at time $\mathrm{t}$ in the ith panel, there are $J_{i}$ dependent stationary variables $X_{i, j, t}\left(\mathrm{j}=1, \ldots, J_{i}\right)$ and $K_{i}$ independent stationary variables $Y_{i, k, t}\left(\mathrm{k}=1, \ldots, K_{i}\right)$. To test the linear causality relationship between two vectors of stationary time series,

$X_{t}=\left(X_{1,1, t}, \ldots, X_{1, J_{1}, t}, \ldots, X_{I, 1, t}, \ldots, X_{I, J_{I}, t}\right)^{\prime} \quad$ and $\quad Y_{t}=$ $\left(Y_{1,1, t}, \ldots, Y_{1, K_{1}, t}, \ldots, Y_{I, 1, t}, \ldots, Y_{I, K_{I}, t}\right)^{\prime}$, one could construct the following vector autoregressive regression (VAR) model:

$$
\left(\begin{array}{c}
X_{t} \\
Y_{t}
\end{array}\right)=\left(\begin{array}{c}
A_{x\left[n_{1} \times 1\right]} \\
A_{y\left[n_{1} \times 1\right]}
\end{array}\right)+\left(\begin{array}{ll}
A_{x x}(L)_{\left[n_{1} \times n_{1}\right]} & A_{x y}(L)_{\left[n_{1} \times n_{2}\right]} \\
A_{y x}(L)_{\left[n_{2} \times n_{1}\right]} & A_{y y}(L)_{\left[n_{2} \times n_{2}\right]}
\end{array}\right)\left(\begin{array}{c}
X_{t-1} \\
Y_{t-1}
\end{array}\right)+\left(\begin{array}{c}
\varepsilon_{x} \\
\varepsilon_{y}
\end{array}\right)
$$

where $A_{x\left[n_{1} \times 1\right]}$ and $A_{y\left[n_{2} \times 1\right]}$ are two vectors of intercept terms, $A_{x x}(L)_{\left[n_{1} \times n_{1}\right]}$, $A_{x y}(L)_{\left[n_{1} \times n_{2}\right]}, A_{y x}(L)_{\left[n_{2} \times n_{1}\right]}$, and $A_{y y}(L)_{\left[n_{2} \times n_{2}\right]}$ are matrices of lag polynomials, $e_{x, t}$ and $e_{y, t}$ are the corresponding error terms, $n_{1}=\sum \sum J_{i}, n_{2}=\sum \sum K_{i}$, and we can rewrite $\left(X_{1,1, t}, \ldots, X_{1, J_{1}, t}, \ldots, Y_{I, 1, t}, \ldots, Y_{I, J_{I}, t}\right)^{\prime}=\left(X_{1, t}, \ldots, X_{n_{1}, t}\right)^{\prime}$. $\left(Y_{1,1, t}, \ldots, Y_{1, K_{1}, t}, \ldots, Y_{I, 1, t}, \ldots, Y_{I, K_{I}, t}\right)^{\prime}=\left(Y_{1, t}, \ldots, Y_{n_{2}, t}\right)^{\prime}$.

Testing the linear causality relationship between $X_{t}$ and $Y_{t}$ is equivalent to testing the following null hypotheses: $H_{0}^{1}: A_{x y}(L)=0$ and $H_{0}^{2}: A_{y x}(L)=0$. There are four different situations for the causality relationships between $X_{t}$ and $Y_{t}$ in (1): (a) rejecting $H_{0}^{1}$ but not rejecting $H_{0}^{2}$ implies a unidirectional causality from $X_{t}$ to $Y_{t}$, (b) rejecting $H_{0}^{2}$ but not rejecting $H_{0}^{1}$ implies a unidirectional causality from $Y_{t}$ to $X_{t}$, (c) 
rejecting both $H_{0}^{1}$ and $H_{0}^{2}$ implies existence of feedback relations between $Y_{t}$ and $X_{t}$, and (d) not rejecting both $H_{0}^{1}$ and $H_{0}^{2}$ implies that $Y_{t}$ and $X_{t}$ are not rejected to be independent.

To test $H_{0}^{1}$ and/or $H_{0}^{2}$, one may first obtain the residual covariance matrix $\sum$ from the full model in (1) without imposing any restriction on the parameters, and compute the residual covariance matrix $\sum_{0}$ for the restricted model in (1) with the restriction on the parameters imposed by the null hypothesis, $H_{0}^{1}$ and/or $H_{0}^{2}$. Thereafter, one could use the $F$-test or the likelihood ratio statistic $(T-C)\left(\log \left|\sum_{0}\right|-\log \left|\sum\right|\right)$ suggested in Sims (1980) to test for $H_{0}^{1}$ and/or $H_{0}^{2}$ where $T$ is the number of usable observations, $c$ is the number of parameters estimated in the unrestricted system.

\subsection{Panel nonlinear causality test}

Baek and Brock (1992) and Hiemstra and Jones (1994) develop the test of nonlinear causality for the bivariate setting while Bai, et al. $(2010,2011)$ extend the test to the multivariate setting. In this paper, we modify their approach to fit in the panel setting. To test whether there is any nonlinear causality relationship between two vectors of stationary panel time series, $X_{t}=\left(X_{1,1, t}, \ldots, X_{1, J_{1}, t}, \ldots, X_{I, 1, t}, \ldots, X_{I, J_{I}, t}\right)^{\prime}$ and $Y_{t}=$ $\left(Y_{1,1, t}, \ldots, Y_{1, K_{1}, t}, \ldots, Y_{I, 1, t}, \ldots, Y_{I, K_{I}, t}\right)^{\prime}$, one has to apply the VAR model as stated in equation (1) to the series $X_{t}$ and $Y_{t}$ to identify their linear causal relationships and obtain their corresponding residuals $\varepsilon_{y, t}$ and $\varepsilon_{x, t}$. Thereafter, one has to apply a nonlinear Granger causality test to the residual series $\varepsilon_{y, t}$ and $\varepsilon_{x, t}$. We rewrite $\left(X_{1,1, t}, \ldots, X_{1, J_{1}, t}, \ldots, Y_{I, 1, t}, \ldots, Y_{I, J_{I}, t}\right)^{\prime} \quad=\quad\left(X_{1, t}, \ldots, X_{n_{1}, t}\right)^{\prime}$ $\left(Y_{1,1, t}, \ldots, Y_{1, K_{1}, t}, \ldots, Y_{I, 1, t}, \ldots, Y_{I, K_{I}, t}\right)^{\prime}=\left(Y_{1, t}, \ldots, Y_{n_{2}, t}\right)^{\prime}$ and without loss of generality, 
we assume that $X_{t}$ and $Y_{t}$ are the corresponding residuals $\varepsilon_{x, t}$ and $\varepsilon_{y, t}$. We first define the lead vector and lag vector of a time series, say $X_{i, t}$, as follows: for

$X_{i, t}, \mathrm{i}=1,2$, the $m_{x_{i}}$-length lead vector and the $L_{x_{i}}$-length lag vector of $X_{i, t}$ are:

$X_{i, t}^{m_{x_{i}}} \equiv\left(X_{i, t}, X_{i, t+1}, \ldots, X_{i, t+m_{x_{i}}-1}\right), m_{x_{i}}=1,2, \ldots, t=1,2, \ldots$,

$X_{i, t-L_{x_{i}}}^{L_{x_{i}}} \equiv\left(X_{i, t-L_{x_{i}}}, X_{i, t-L_{x_{i}}+1}, \ldots, X_{i, t-1}\right), L_{x_{i}}=1,2, \ldots, \mathrm{t}=L_{x_{i}}+1, L_{x_{i}}+2, \ldots$

respectively. We denote $M_{x}=\left(m_{x 1}, \ldots, m_{x_{n_{1}}}\right), L_{x}=\left(L_{x 1}, \ldots, L_{x_{n_{1}}}\right), m_{x}=$ $\max \left(m_{x 1}, \ldots, m_{n_{1}}\right)$, and $l_{x}=\max \left(L_{x 1}, \ldots, L_{x_{n_{1}}}\right)$. The $m_{y_{i}}$-length lead vector, $Y_{i, t}^{m_{y_{i}}}$ the $L_{y_{i}}$-length lag vector, $Y_{i, t-L_{y_{i}}}^{L_{y_{i}}}$ of $Y_{i, t}$, and $M_{y}, L_{y}, m_{y}$, and $l_{y}$ can be defined similarly.

Given $m_{x}, m_{y}, L_{x}, L_{y}$, and $e>0$, we define the following four events:

$\left\{\left\|X_{t}^{M_{x}}-X_{s}^{M_{x}}\right\|<e\right\} \equiv\left\{\left\|X_{i, t}^{M_{x_{i}}}-X_{i, s}^{m_{x_{i}}}\right\|<e\right.$, for any $\left.i=1, \ldots, n_{1}\right\}$

$\left\{\left\|X_{t-L_{x}}^{L_{x}}-X_{s-L_{x}}^{L_{x}}\right\|<e\right\} \equiv\left\{\left\|X_{i, t-L_{x_{i}}}^{L_{x_{i}}}-X_{i, s-L_{x_{i}}}^{L_{x_{i}}}\right\|<e\right.$, for any $\left.i=1, \ldots, n_{1}\right\}$

$\left\{\left\|Y_{t}^{M_{y}}-Y_{s}^{M_{y}}\right\|<e\right\} \equiv\left\{\left\|Y_{i, t}^{m_{y_{i}}}-Y_{i, s}^{m_{y_{i}}}\right\|<e\right.$, for any $\left.i=1, \ldots, n_{2}\right\} ;$ and

$\left\{\left\|Y_{t-L_{y}}^{L_{y}}-Y_{s-L_{y}}^{L_{y}}\right\|<e\right\} \equiv\left\{\left\|Y_{i, t-L_{y_{i}}}^{L_{y_{i}}}-Y_{i, s-L_{y_{i}}}^{L_{y_{i}}}\right\|<e\right.$, for any $\left.i=1, \ldots, n_{2}\right\}$

where $\|\cdot\|$ denotes the maximum norm which is defined as $\|X-Y\|=\max \left(\mid x_{1}-\right.$ $\left.y_{1}|,| x_{2}-y_{2}|, \ldots,| x_{n}-y_{n} \mid\right)$ for any two vectors $\mathrm{X}=\left(x_{1}, \ldots, x_{n}\right)$ and $\mathrm{Y}=\left(y_{1}, \ldots, y_{n}\right)$. The vector series $\left\{Y_{t}\right\}$ is said not to strictly Granger cause another vector series $\left\{X_{t}\right\}$ if $\operatorname{Pr}\left(\left\|X_{t}^{M_{x}}-X_{s}^{M_{x}}\right\|<e \mid\left\|X_{t-L_{x}}^{L_{x}}-X_{s-L_{x}}^{L_{x}}\right\|<e,\left\|Y_{t-L_{y}}^{L_{y}}-Y_{s-L_{y}}^{L_{y}}\right\|<e,\right)$ 
$=\operatorname{Pr}\left(\left\|X_{t}^{M_{x}}-X_{s}^{M_{x}}\right\|<e \mid\left\|X_{t-L_{x}}^{L_{x}}-X_{s-L_{x}}^{L_{x}}\right\|<e\right)$

where $\operatorname{Pr}(\cdot \mid \cdot)$ denotes conditional probability. Under this modeling setting, we extend

Baek and Brock (1992), Hiemstra and Jones (1994), and Bai, et al. (2010, 2011) to obtain the following theorem to test whether there is any nonlinear causality relationship between two vectors of stationary panel time series, $X_{t}=$ $\left(X_{1,1, t}, \ldots, X_{1, J_{1}, t}, \ldots, X_{I, 1, t}, \ldots, X_{I, J I}, t\right)^{\prime}$ and $Y_{t}=\left(Y_{1,1, t}, \ldots, Y_{1, K_{1}, t}, \ldots, Y_{I, 1, t}, \ldots, Y_{I, K_{I}, t}\right)^{\prime}:$

Theorem 1. To test the null hypothesis, $H_{0}$, that $Y_{t}=$ $\left(Y_{1,1, t}, \ldots, Y_{1, K_{1}, t}, \ldots, Y_{I, 1, t}, \ldots, Y_{I, K_{I}, t}\right)^{\prime}$ does not strictly Granger cause $\left(X_{1,1, t}, \ldots, X_{1, J_{1}, t}, \ldots, X_{I, 1, t}, \ldots, X_{I, J_{I}, t}\right)^{\prime}$ under the assumptions that the time series panel variables $\left(X_{1,1, t}, \ldots, X_{1, J_{1}, t}, \ldots, X_{I, 1, t}, \ldots, X_{I, J I}, t\right)^{\prime}$ and $\left(Y_{1,1, t}, \ldots, Y_{1, K_{1}, t}, \ldots, Y_{I, 1, t}, \ldots, Y_{I, K_{I}, t}\right)^{\prime}$ are strictly stationary, weakly dependent, and satisfy the mixing conditions stated in Denker and Keller (1983), if the null hypothesis, $H_{0}$, is true, the test statistic

$$
\sqrt{n}\left(\frac{C_{1}\left(M_{x}+L_{x}, L_{y}, e, n\right)}{C_{2}\left(L_{x}, L_{y}, e, n\right)}-\frac{C_{3}\left(M_{x}+L_{x}, e, n\right)}{C_{4}\left(L_{x}, e, n\right)}\right)
$$

is distributed as $N\left(0, \sigma^{2}\left(M_{x}, L_{x}, L_{y}, e\right)\right)$. When the test statistic is too far away from zero, we reject the null hypothesis. A consistent estimator of $\sigma^{2}\left(M_{x}, L_{x}, L_{y}, e\right)$ is $\left.\hat{\sigma}^{2}\left(M_{x}, L_{x}, L_{y}, e\right)=\overline{\nabla f(\theta}\right)^{T} \cdot \widehat{\Sigma} \cdot \widehat{\nabla f(\theta)}$.

Readers may refer to Bai, et al. $(2010,2011)$ for more information on the covariance matrix $\sum$ and modify the proof in Bai, et al. $(2010,2011)$ to obtain the proof of Theorem 1. The difference of the test stated in Theorem 1 is that it can be used to compare variables in the bivariate, multivariate and panel settings while the test in Baek and Brock (1992) and Hiemstra and Jones (1994) can be used to compare variables in the bivariate setting and the tests developed by Bai, et al. $(2010,2011)$ can be used for variables in both bivariate and multivariate settings. 
In this paper, $\mathrm{I}=2, J_{1}=J_{2}=K_{1}=K_{2}=1, n_{1}=n_{2}=2, Y_{t}=\left(Y_{1, t}, Y_{2, t}\right)^{\prime} X_{t}=$ $\left(X_{1, t}, X_{2, t}\right)^{\prime}$. Since both indices (housing indices and EPUs) are I(1) and are not cointegrated (as will be shown in detail in Section 3 below), housing returns (defined as the first-difference of the natural log of the housing prices) and EPU growth (defined as the first-differences of the natural log of EPUs) - both stationary variables, are used in our analysis. We let $Y_{1, t}$ and $X_{1, t}$ be housing returns and the difference of EPU for China and $Y_{2, t}$ and $X_{2, t}$ be housing return and the difference of EPU for India at time $t$. We let $Y_{t}=\left(Y_{1, t}, Y_{2, t}\right)^{\prime} \quad X_{t}=\left(X_{1, t}, X_{2, t}\right)^{\prime}$, and in this paper we will analyze the relationship between $Y_{t}$ and $X_{t}$.

\section{Empirical Results}

\subsection{Summary Statistics}

Table 1 shows the summary statistics of our data. They show, for example, that log housing prices (China and India) fall within a range from 4.05 to 4.74 , with a mean value of 4.59 and 4.49 for China and India while EPU indices (China and India), on the other hand, fall within the range from 3.57 to 5.71 , with a mean value of 4.69 and 4.47 for China and India, respectively. The skewness estimates reveal all housing price series are skewed to the left while all uncertainty series are skewed to the right. However, the normality hypotheses are not rejected when Jarque-Bera statistics are used for all variables in both countries. The summary statistics for the first difference of log housing prices (China and India) and EPU indices are also reported in Table 1. The first differences of log housing price of China ( $\triangle$ Housing Price (China)) and India $(\Delta$ Housing Price (India)) have mean values around 0.0065 and 0.0177 , respectively. The mean values of EPU first differences in China $(\triangle E P U($ China $))$ and India $(\triangle E P U$ (India)) are 0.0161 and 0.0152 , respectively. The Jarque-Bera statistics suggest that 
only the $\Delta$ Housing Price (India) is not normally distributed. Charts of differences of log housing price and EPU first differences are shown in Figure 1 and Figure 2.

(Insert Table 1 around here)

\section{(Insert Figure 1 and Figure 2 around here)}

\subsection{Unit Root Tests}

Table 2 shows the results of the panel unit root test. In order to have more reliable results, we apply both Levin-Lin-Chu test (2002, LLC test) and Im-Pesaran-Shin test (2003, IPS test) to test for the existence of unit roots in the panel data models ${ }^{4}$. Both tests suggest that the series of housing prices and uncertainty contain a unit root while their first differences do not contain unit roots. Thus, we conclude that both housing price and uncertainty are I(1) variables. Table 3 shows the results of the Ng-Perron (2001) unit root tests to determine whether housing prices and EPU indexes contain unit $\operatorname{root}(\mathrm{s})$ and whether housing return and EPU growth contain a unit root. The results suggest that both variables contain a unit root, while their first differences are found to be stationary. Since causality analysis requires the data to be stationary, in this paper we will examine whether there is any linear and nonlinear causality between housing returns and EPU growth rates for both China and India.

\section{(Insert Tables 2 and 3 around here)}

\subsection{Cointegration}

Before testing for causality, we test for cointegration between the variables. Table 4 shows the results of Pedroni $(1999,2004)$ panel cointegration test. The null hypothesis of no cointegration between housing prices and uncertainty indexes is examined in both

\footnotetext{
${ }^{4}$ Because the number of lags introduced in equation (1) is an important decision, and various informational criteria could lead to different number of lags to be chosen, in this paper we choose the number of lags to be one to four in the testing so that it could fit different criteria.
} 
countries. Null hypothesis of no cointegration between housing price and uncertainty is not rejected in any of the cases. The results are exactly the same when we test the cointegration hypothesis using individual country's data using the Engle and Granger (1987) approach. In addition, the results in Table 5 also confirm that the no cointegration null hypothesis, cannot be rejected in any of the countries.

\section{(Insert Tables 4 and 5 around here)}

\subsection{Panel Linear Granger Causality}

Since there is no cointegration between housing prices and uncertainty levels for both China and India, we apply the model stated in (1) to test whether there is a linear Granger causality relationship between changes in EPU and housing market returns in both China and India. As shown in Table 6, the results suggest that there is a marginally significant panel linear Granger causality from changes in EPU to housing returns in China and India, while there is no evidence of a panel linear Granger causality relationship from housing market returns in India and China to EPU changes in these countries. That is, the main results suggest that economic policy uncertainty shocks could help us predict future changes in housing market returns, while these returns cannot predict movements in the economic policy uncertainty indices.

\section{(Insert Table 6 around here)}

\subsection{Individual Linear Granger Causality}

As a complementary analysis of the panel linear Granger causality tests for both countries, Table 7 shows the individual linear Granger causality tests for each of the countries. These results suggest that there is a strongly significant unidirectional linear Granger causality relationship from Chinese changes in EPU to Chinese housing returns, while there is no causality relationship between these two variables in India. That is, while changes in EPU could help explaining future changes in housing returns in China, 
they will not give any information on the future behavior of housing returns in India.

The higher degree of development of the housing market in China than in India, together with the more proactive role of the Chinese government in terms of property market management than the Indian one might explain why changes in EPU have a significant impact on housing returns in China and not in India.

\section{(Insert Table 7 around here)}

\subsection{Panel Non-Linear Granger Causality}

As far as the possible existence of a non-linear relationship between housing market returns and changes in EPU is concerned, Table 8 shows the results of the panel nonlinear Granger causality tests among these variables. ${ }^{5}$ The main results suggest the existence of a non-linear unidirectional Granger causality relationship from changes in EPU to housing market returns, while the results do not support the existence of any nonlinear relationship from housing returns to changes in EPU.

\section{(Insert Table 8 around here)}

\subsection{Individual Non-Linear Granger Causality}

Again, and as a complementary analysis of the panel nonlinear Granger causality tests for both countries, Table 9 exhibits the results of the individual nonlinear Granger causality tests for each of the countries. Contrary to the results obtained with the linear tests (see Table 7) that there exists only unidirectional "linear" relationship from Chinese EPU changes to Chinese housing returns, the nonlinear Granger causality tests (see Table 9) suggest that there exists bidirectional nonlinear Granger causality relationships between EPU changes and housing returns not only in Chinese market, but

\footnotetext{
${ }^{5}$ To examine whether this is any nonlinearity in the variables, we conducted the Brock et al., (1996, BDS) test. We found that there is evidence of nonlinearity in the relationship between the real housing returns and growth rate of EPU for both countries. In addition, when we used the structural break tests of Bai and Perron (2003), though we could not detect any break when the growth rate of EPU is the dependent variable for both countries, five breaks were detected for both China and India, when the real housing returns was the dependent variable. The breaks for China (India) were at: 2005:01, 2007:04, 2009:01, 2010:02 and 2011:04 (2005:01, 2007:01, 2008:02, 2010:02 and 2011:03). Complete details of these results are available upon request from the authors.
} 
also in Indian market. Nonetheless, the nonlinear Granger causality relationships from EPU changes to housing returns in both China and India are strongly significant at $1 \%$ while the nonlinear Granger causality relationships from housing returns to EPU changes in both China and India are only marginally significant at $10 \%$. This implies that while changes in EPU could help to explain future changes in housing returns strongly in both China and India, housing returns in these countries (though not very strong) could also be used to determine the future economic policy uncertainty changes in these two countries. The results obtained in the paper are in line with those obtained by Antonakakis et al. (2015), who analyze the relationship between these two variables for the US economy, but differ from those obtained by Su et al. (2016), who analyze the relationship between these two variables in Germany, a country with a more developed housing market, and find the existence of a causality relationship from housing market returns to economic policy uncertainty. Similar results to Su et al. (2016) are found by El Montasser et al. (forthcoming) for the US and the UK economies, while for Canada, Germany and Italy, this last paper finds unidirectional causality from policy uncertainty to housing market returns, in line with the results we obtain for China and India.

\section{(Insert Table 9 around here)}

As a robustness check, based on the suggestion of an anonymous referee, we also conducted the analysis for the pre and post-crisis periods corresponding to 2003:Q22007:Q4 and 2008:Q1-2012:Q4 respectively. These results have been reported in Tables A1 to A4 in the Appendix of the paper. As can be seen from Tables A1-A4, our results for the full-sample hold in general. But an interesting observation can be made, which is that, the full-sample results are primarily driven by the post-crisis period, suggesting that uncertainty and housing returns were more closely causally related in the post-crisis period. 


\subsection{Cross Granger Causality}

Finally, and in order to account for international uncertainty or housing market spillovers, we test for cross causality between changes in EPU from one country to the housing returns in the other country, and vice versa. We first test the hypotheses for the linear case and report the results in Table 10 and test the hypotheses for the nonlinear case and report the results in Table 11 . From Tables 10 and 11, we only observe a linear causality relationship from Indian changes in EPU to Chinese housing returns, while when nonlinear causality tests are carried out, no evidence of a nonlinear causality relationship between the variables is found.

\section{(Insert Tables 10 and 11 around here)}

\section{Conclusions}

In this paper, we first modify the multivariate nonlinear causality test to be panel nonlinear causality test and we recommend academics and practitioners to carry out cross linear and nonlinear causality tests in their study. Thereafter, we apply the tests we proposed, the existing linear and nonlinear causality tests and other existing related tests to examine the causal relationship between Economic Policy Uncertainty (EPU) and real housing returns in China and India using monthly data from January 1998 to December 2014. The high economic policy uncertainty (EPU) levels observed during the last decade, together with the data availability to measure it explain the great amount of papers that have already analysed the macroeconomic impact of changes in EPU on different variables. In this context, this paper examines the role of changes in EPU on the housing returns in the two largest emerging economies, China and India, using quarterly data from 2003:01 to 2012:04, by means of using both linear and nonlinear panel and bivariate Granger causality tests. 
One of the main results suggests that the conclusions depend on the methodology used to test for causality relationships. Thus, while only a unidirectional relationship from changes in EPU to housing returns in China is obtained when linear causality tests are applied, the results are different when nonlinear causality tests are employed. In the latter case, bidirectional causality relationships are found between changes in EPU and housing returns in both China and India.

Based on the nonlinear Granger causality tests, the results suggests that changes in EPU will help to understand and predict future changes in housing market returns in both India and China, while housing returns will also help (but not as strong) to explain future changes in policy uncertainty indices in both countries. Finally, according to the results obtained with this methodology, when cross causality relationships between these two variables from one country to the other are analyzed, the results shows only the existence of a linear causality relationship from Indian changes in EPU to Chinese housing returns. That is, changes in EPU in India will not only determine housing markets in India (in a non-linear way), but also influence housing markets in China (linearly), but not the other way round. Furthermore, housing markets in India will not determine EPU changes in any of the countries.

Nevertheless, the linear panel results do not allow to draw general conclusions about nonlinear causality in both China and India though both the linear and nonlinear panel results conclude that there is only Granger causality relationships from EPU changes to housing returns but not from housing returns to EPU changes. The linear panel results can only be used to conclude that there is linear Granger causality relationships from EPU changes to housing returns but cannot be used to conclude existence of any nonlinear relationship between EPU changes and housing returns. On the other hand, the nonlinear panel results could be used to conclude that there exists nonlinear Granger 
causality relationship from EPU changes to housing returns but this could not guarantee that there exist any linear relationship between EPU changes and housing returns. In addition, as discussed before, the findings of bivariate linear and nonlinear causality could be different from the findings of panel linear and nonlinear causality. Thus, we recommend academics and practitioners not only apply bivariate linear and nonlinear causality but also panel linear and nonlinear causality in their study.

Due to the relevance of predicting housing market returns for different agents, such as homeowners, investors, policymakers, real estate companies and financial institutions, and the new availability of EPU data, the existence of a relationship between changes in EPU and housing returns is very important since the EPU indices will give all these agents information to help them predict the behaviour of the still volatile and quite unpredictable housing market. Since evidence of in-sample predictability does not guarantee out-of-sample gains (Christou et al., forthcoming), as part of future research, it would be interesting to extend our analysis to a forecasting exercise. Also, from a more technical perspective, it would be worthwhile to extend our nonlinear causality tests to a multivariate framework, given that real housing returns and EPU are likely to be driven by other important variables as well, for instance, growth of the economy, monetary policy stance, inflation, etc. 


\section{References}

Aasveit, K., Gisle, J. and Sola, S. (2013). Economic uncertainty and the effectiveness of monetary policy. Norges Bank. No. 2013/17.

Antonakakis, N., Chatziantoniou, I. and Filis, G. (2013). Dynamic co-movements between stock market returns and policy uncertainty. Economics Letters 120, 87-92.

Antonakakis, N., Gupta, R., André, C. (2015). Dynamic Co-movements between Economic Policy Uncertainty and Housing Market Returns. Journal of Real Estate Portfolio Management 21, 53-60.

Antonakakis, N. and Floros, C. (2016). Dynamic interdependencies among the housing market, stock market, policy uncertainty and the macroeconomy in the United Kingdom. International Review of Financial Analysis 44, 111-122.

Antonakakis, N. Balcilar, M., Gupta, R. and Kyei, C. (2016). Components of economic policy uncertainty and predictability of US stock returns and volatility: Evidence from a nonparametric causality-in-quantile approach. Department of Economics, University of Pretoria, Working Paper No. 201639.

Baek,E.G. and Brock, W.A. (1992). A general test for nonlinear Granger causality : bivariate model, working paper, Korea Development Institute, University of WisconsinMadison.

Baker, S. R., Bloom, N. and Davis, S. J. (2015). Measuring economic policy uncertainty. NBER WP No. 21633.

Bai, J. and Perron, P. (2003). Computation and analysis of multiple structural change models. Journal of Applied Econometrics, 18, 1-22.

Bai, Z.D., Wong, W.K., Zhang, B.Z. (2010). Multivariate linear and non-linear causality tests. Mathematics and Computers in Simulation 81, 5-17.

Bai, Z.D., Li, H., Wong, W.K., Zhang, B.Z. (2011). Multivariate causality tests with simulation and application. Statistics and Probability Letters 81, 1063-1071.

Barros, C.P., Gil-Alana, L.A., Payne, J.E. (2015). Modeling the Long Memory Behavior in U.S. Housing Price Volatility. Journal of Housing Research 24, 87-106.

Bernanke, B. S. (1983). Irreversibility, uncertainty, and cyclical investment. The Quarterly Journal of Economics 98, 85-106.

Bloom, N. (2009). The impact of uncertainty shocks. Econometrica 77, 623-685.

Bloom, N., Bond, S. and van Reenen, J. (2007). Uncertainty and investment dynamics. The Review of Economic Studies 74, 291-415. 
Brock, W., Dechert, D., Scheinkman, J., LeBaron, B., (1996). A test for independence based on the correlation dimension. Econometric Reviews, 15, 197-235.

Brogaard, J. and Detzel, A. (2015). The asset-pricing implications of government economic policy uncertainty. Management Science 61, 3-18.

Caggiano, G., Castelnuovo, E. and Groshenny, N. (2014). Uncertainty shocks and unemployment dynamics: An analysis of post-WWII US recessions. Journal of Monetary Economics 67, 78-92.

Caggiano, G., Castelnuovo, E. and Figueres, J.M. (2017). Economic policy uncertainty and unemployment in the United States: A nonlinear approach. Economics Letters 151, 31-34.

Calcagnini, G. and Saltari, E. (2000). Real and financial uncertainty and investment decisions. Journal of Macroeconomics 22, 491-514.

Carriero, A., Mumtaz, H., Theodoridis, K. and Theophilopoulou, A. (2015). The impact of uncertainty shocks under measurement error: A proxy SVAR approach. Journal of Money, Credit and Banking, 47(6), 1223-1238.

Carroll, C. (1996). Buffer-stock saving and the life cycle/permanent income hypothesis. NBER Working Paper No. 5788.

Cesa-Bianchi, A., Cespedes L-F., Rebucci, A. (2015). Global Liquidity, House Prices, and the Macroeconomy: Evidence from Advanced and Emerging Economies. Journal of Money, Credit and Banking, 47 (S1), 301-335.

Chen, J., Jiang, F. and Tong, G. (2016). Economic policy uncertainty in China and stock market expected returns. Available at SSRN: http://ssrn.com/abstract=2808862 or http://dx.doi.org/10.2139/ssrn.2808862.

Christou, C., Gupta, R., and Hassapis, C. (Forthcoming). Does Economic Policy Uncertainty Forecast Real Housing Returns in a Panel of OECD Countries? A Bayesian Approach. Quarterly Review of Economics and Finance.

D'Arcy, P. and Veroude, A. (2014). Housing trends in China and India. Reserve Bank of Australia, Bulletin March Quarter 2014.

Denker, M. and Keller, G. (1983). On U-statistics and v. mise'statistics for weakly dependent processes, Zeitschrift für Wahrscheinlichkeitstheorie und Verwandte Gebiete 64 (4), 505-522.

Dixit, A. K. and Pindyck, R. S. (1994). Investment under uncertainty. Princeton University Press.

El Montasser, G., Ajmi, A. N., Chang, T., Simo-Kengne, B. D., Andre, C., Gupta, R., (Forthcoming). Cross-Country Evidence on the Causal Relationship between Policy Uncertainty and House Prices. Journal of Housing Research. 
Engle, R.F. and Granger, CW.J. (1987). Co-integration and error correction: Representation, estimation and testing, Econometrica, 55 (2), 251-276.

Fernández-Villaverde, J., Guerrón-Quintana, P., Kuester, K. and Rubio-Ramírez, J. (2015). Fiscal volatility shocks and economic activity. American Economic Review 105, 3352-3384.

Friedman, M. (1968). The role of monetary policy. American Economic Review 58, 117.

Guirguis, H.S., Giannikos, C., Anderson, R.I. (2005). The U.S. Housing Market: Asset Pricing Forecasts Using Time-varying Coefficients. Journal of Real Estate Finance and Economics, 30, 33-53.

Gulen, H. and Ion, M. (2015). Policy uncertainty and corporate investment. http://papers.ssrn.com/sol3/papers.cfm?abstract_id=2188090.

Hatemi-J, A. (2012). Asymmetric causality tests with an application. Empirical Economics, 43(1), 447-456.

Hiemstra, C. and Jones, J.D. (1994). Testing for linear and nonlinear Granger causality in the stock price-volume relation. Journal of Finance 49, 1639-1664.

Iacoviello, M. and Neri, S. (2010). Housing market spillovers: Evidence from an estimated DSGE model. American Economic Journal: Macroeconomics 2, 125-164.

Im K.S, Pesaran M.H, and Shin, Y. (2003). Testing for Unit Roots in Heterogeneous Panels, Journal of Econometrics, 115, 53-74.

International Monetary Fund, (2012). World Economic Outlook: Coping with High Debt and Sluggish Growth. October, IMF Press.

International Monetary Fund (2013). World Economic Outlook: Hopes, Realities, Risks. April, IMF Press.

Jurado, K., Ludvigson, S. C. and Ng, S. (2015). Measuring uncertainty. The American Economic Review 105, 1177-1216.

Kang, W. and Ratti, R. A. (2015). Oil shocks, policy uncertainty and stock returns in China. Economics of Transition, 23(4), 657-676.

Leamer, E. E. (2007). Housing is the Business Cycle. Proceedings -Economic Policy Symposium- Jackson Hole, Federal Reserve Bank of Kansas City, 149-233.

Levin A., Lin C.F., Chu C.J. (2002). Unit root tests in panel data: asymptotic and finitesample properties, Journal of Econometrics, 108, 1-24. 
Li, X., Balcilar, M., Gupta, R. and Chang, T. (2015). The causal relationship between economic policy uncertainty and stock returns in China and India: Evidence from a bootstrap rolling-window approach. Emerging Markets Finance and Trade 52, 674-689.

Ludvigson, S. C., Ma, S. and Ng, S. (2015). Uncertainty and business cycles: Exogenous impulse or endogenous response? NBER Working Paper No. 21803.

McDonald, R. and Siegel, D. (1986). The value of waiting to invest. The Quarterly Journal of Economics 101, 707-727.

Mian, A. and Sufi, A. (2011). House prices, home equity-based borrowing and the US household leverage crisis. American Economic Review 101, 2132-2156.

Miles, W. (2008) Volatility Clustering in U.S. Home Prices. Journal of Real Estate Research, 30 93-113.

Miller, N.G. and Peng, L. (2006). Exploring Metropolitan Housing Price Volatility. Journal of Real Estate Economics and Finance, 33(1), 5-18.

Mumtaz, H. and Surico, P. (2013). Policy uncertainty and aggregate fluctuations. Queen Mary University of London, School of Economics and Finance, Working Paper No. 708.

Mumtaz, H. and Zanetti, F. (2013). The impact of the volatility of monetary policy shocks. Journal of Money, Credit and Banking 45, 535-558.

Mumtaz, H. and Theodoridis, K. (2015). Common and country specific economic uncertainty. Queen Mary University of London, School of Economics and Finance, Working Paper No. No. 752.

Nodari, G. (2014). Financial regulation policy uncertainty and credit spreads in the US. Journal of Macroeconomics 41, 122-132.

Nyakabawo, W., Miller, S. M., Balcilar, M., Das, S., and Gupta, R. (2015). Temporal causality between housing prices and output in the US: A bootstrap rolling-window approach. North American Journal of Economics and Finance 33, 55-73.

Pastor, L. and Veronesi, P. (2012). Uncertainty about government policy and stock prices. The Journal of Finance 67, 1219-1264.

Pastor, L. and Veronesi, P. (2013). Political uncertainty and risk premia. Journal of Financial Economics 110, 520-545.

Pedroni P. (1999), Critical Values for Cointegration Tests in Heterogeneous Panels with Multiple Regressors, Oxford Bulletin of Economics and Statistics, Vol. 61, pp 653-670.

Pedroni P. (2004), Panel Cointegration; Asymptotic and Finite Sample Properties of Pooled Time series Tests, With an Application to the PPP Hypothesis, Econometric Theory, 20, 597-625. 
Rossi, B. and Sekhposyan, T. (2015). Macroeconomic uncertainty indices based on nowcast and forecast error distributions. The American Economic Review 105, 650-655.

Shoag, D. and Veuger, S. (2013). Uncertainty and the geography of the Great Recession. AEI Economics Working Paper 2013-05.

Sims, C. (1980). Macroeconomics and Reality. Econometrica 48, 1-48.

Singh, C., Kumar, L. and Prasad, H. (2014). Housing market in India. Indian Institute of Management Bangalore, December 2014.

Strobel, J. (2015). On the different approaches of measuring uncertainty shocks. Economics Letters 134, 69-72.

Sum, V. (2012a). The reaction of stock markets in the BRIC countries to economic policy uncertainty in the United States. SSRN Paper No. 2094697.

Su, D., X. Li, O.-R. Lobonţ and Zhao, Y. (2016). Economic policy uncertainty and housing returns in Germany, Zbornik radova Ekonomskog fakulteta u Rijeci, časopis za ekonomsku teoriju i praksu - Proceedings of Rijeka Faculty of Economics, Journal of Economics and Business 34, 43-61.

Sum, V. (2012b). How do stock markets in China and Japan respond to economic policy uncertainty in the United States? SSRN Paper No. 2092346.

World Bank (2015). How important are China and India in global commodity consumption? Commodity Markets Outlook, July 2015.

Yin, L. and Han, L. (2014). Spillovers of macroeconomic uncertainty among major economies. Applied Economics Letters 21, 938-944. 
Table 1 Summary statistics

\begin{tabular}{|c|c|c|c|c|c|c|c|}
\hline Variable & Max & Min & Mean & SD & Skewness & Kurtosis & $\begin{array}{c}\text { Jarque- } \\
\text { Bera } \\
\end{array}$ \\
\hline $\begin{array}{l}\text { Housing Price } \\
\text { (China) }\end{array}$ & 4.7159 & 4.4129 & $4.5920 * * *$ & $0.0864 * * *$ & -0.5334 & 2.2857 & 2.7473 \\
\hline $\begin{array}{l}\Delta \text { Housing Price } \\
\text { (China) }\end{array}$ & 0.0309 & -0.0287 & $0.0065 * * *$ & $0.0134 * * *$ & $-0.6573 *$ & 2.9957 & 2.8086 \\
\hline $\begin{array}{l}\text { Housing Price } \\
\text { (India) }\end{array}$ & 4.7434 & 4.0537 & $4.4865 * * *$ & $0.2206 * * *$ & $-0.6502 *$ & $1.9952 * *$ & 4.5008 \\
\hline $\begin{array}{l}\Delta \text { Housing Price } \\
\text { (India) }\end{array}$ & 0.1258 & -0.1284 & $0.0177 * * *$ & $0.0404 * * *$ & $-0.7332 * *$ & $6.7969 * * *$ & $26.92 * * *$ \\
\hline EPU (China) & 5.7098 & 3.8729 & $4.6932 * * *$ & $0.4723 * * *$ & 0.5479 & 2.2821 & 2.8604 \\
\hline$\triangle E P U($ China $)$ & 0.8274 & -0.8203 & 0.0161 & $0.2982 * * *$ & -0.0215 & 4.0047 & 1.6434 \\
\hline $\begin{array}{l}E P U \\
\text { (India) }\end{array}$ & 5.4219 & 3.5710 & $4.4697 * * *$ & $0.5236 * * *$ & 0.1838 & $1.9470 * *$ & 2.0732 \\
\hline $\begin{array}{l}\triangle E P U \\
\text { (India) }\end{array}$ & 0.8636 & -0.5783 & 0.0152 & $0.0404 * * *$ & $0.6928 *$ & 3.8045 & 4.1715 \\
\hline
\end{tabular}

Figure 1 Growth Rates of housing price and EPU for China

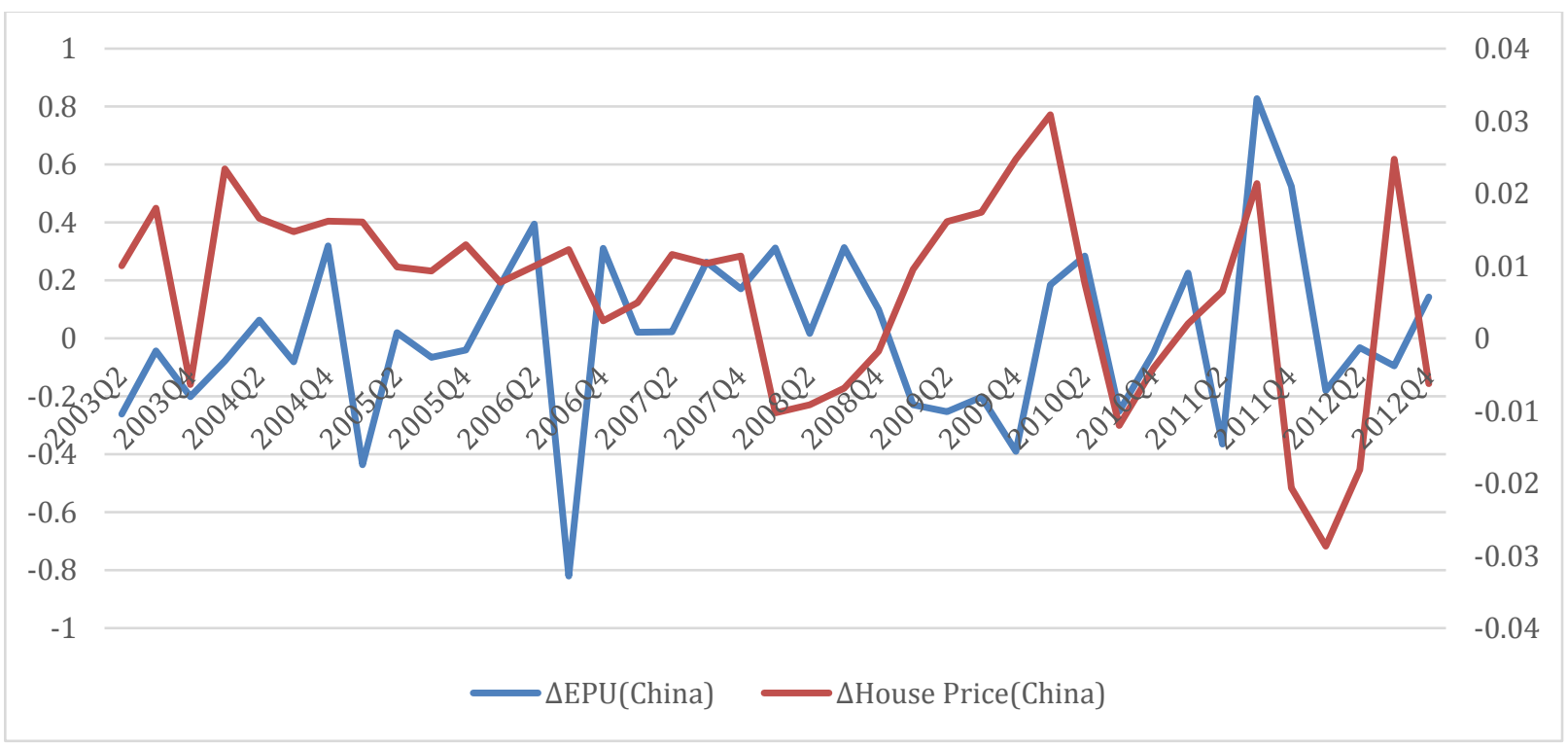


Figure 2. Growth rates of housing price and EPU for India

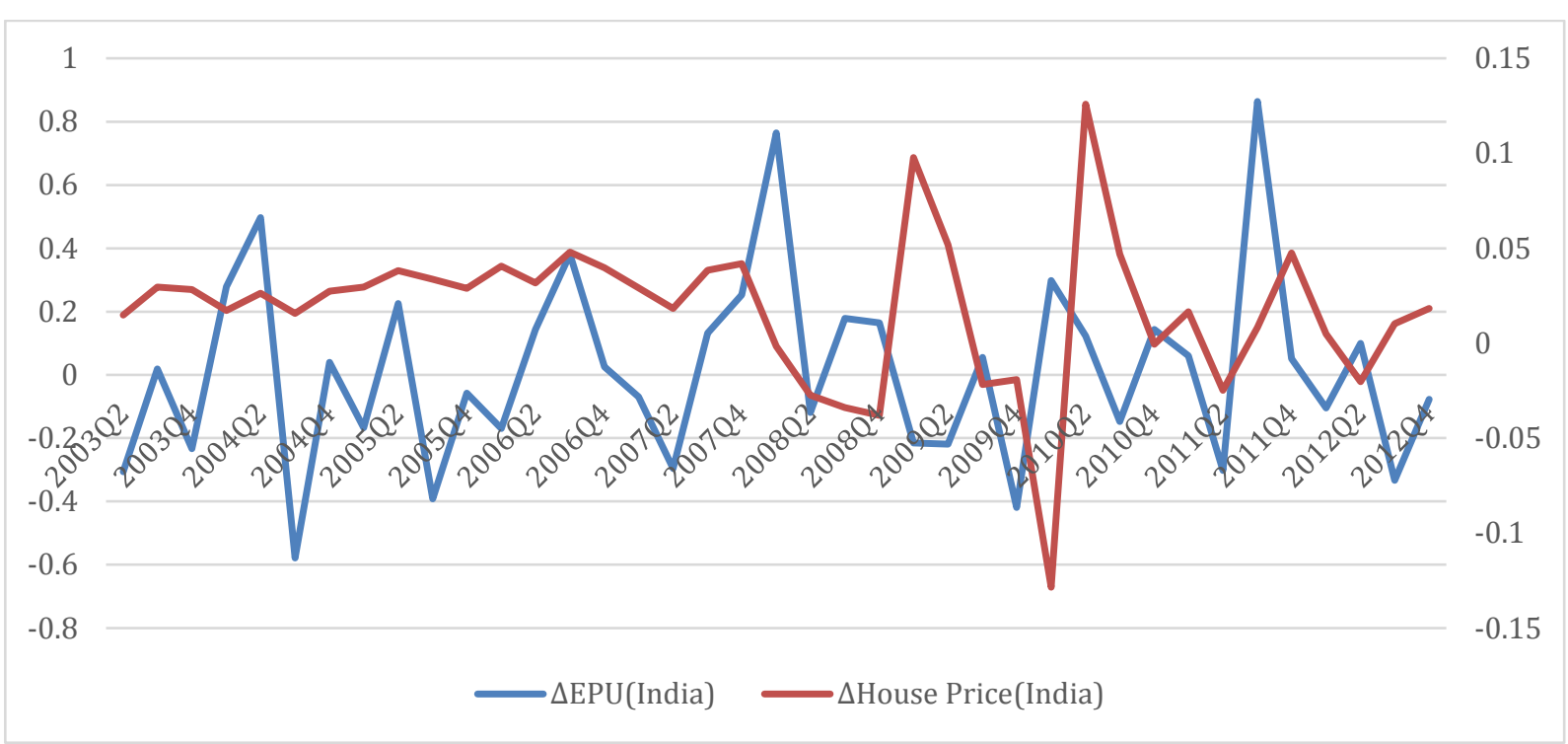

Table 2 Panel unit root test

\begin{tabular}{llllll}
\hline \multirow{2}{*}{ Test statistics } & \multicolumn{2}{l}{ Housing Price } & & & $E P U$ \\
\cline { 2 - 3 } \cline { 5 - 6 } & Level & First difference & & Level & First difference \\
\hline LLC test & -0.712 & $-4.472^{* * *}$ & & 0.046 & $-6.428^{* * *}$ \\
IPS test & 0.898 & $-4.719 * * *$ & & -0.209 & $-9.141^{* * *}$ \\
\hline
\end{tabular}

Notes: The *,**, and *** denote the significance at $10 \%, 5 \%$ and $1 \%$ levels, respectively.

Table 3 Ng-Perron unit root test

\begin{tabular}{llllll}
\hline \multirow{2}{*}{ Country } & \multicolumn{3}{l}{ Housing Price } & & EPU \\
\cline { 2 - 3 } \cline { 5 - 6 } & Level & First difference & & Level & First difference \\
\hline China & 0.491 & $-14.44^{* * *}$ & & $-6.235^{*}$ & $-16.398^{* * *}$ \\
India & 0.791 & $-19.450^{* * *}$ & & -4.975 & $-15.366^{* * * *}$ \\
\hline
\end{tabular}

Notes: The $*, * *$, and $* * *$ denote the significance at $10 \%, 5 \%$ and $1 \%$ levels, respectively.

Table 4. Pedroni panel cointegration test

\begin{tabular}{lrrrr}
\hline & & & & \\
\cline { 2 - 4 } Lags & 1 & 2 & 3 & 4 \\
\hline$v$-Statistic & 0.4388 & 0.6335 & 0.7160 & 0.8182 \\
rho-Statistic & 0.3527 & 0.4603 & 0.7190 & 0.9164 \\
PP-Statistic & 0.3549 & 0.4560 & 0.7118 & 0.9212 \\
ADF-Statistic & 0.3154 & 1.0926 & 1.8488 & 2.3455 \\
\hline
\end{tabular}

Notes: The $*, * *$, and $* * *$ denote the significance at $10 \%, 5 \%$ and $1 \%$ levels, respectively. 
Table 5 Engle-Granger Cointegration test

\begin{tabular}{lrrrr}
\hline & & & & \\
\cline { 2 - 5 } Lags & 1 & 2 & 3 & 4 \\
\hline China & -2.2773 & -2.1509 & -2.3099 & -1.9980 \\
India & -2.2594 & -2.1883 & -1.9169 & -2.0896 \\
\hline \hline
\end{tabular}

Notes: The *,**, and *** denote the significance at $10 \%, 5 \%$ and $1 \%$ levels, respectively.

Table 6 Panel Linear Granger Causality

Null: Housing Return $\quad$ Null: EPU growth

does not cause EPU growth

does not cause Housing Return

\begin{tabular}{|c|c|c|c|c|c|c|c|c|}
\hline & & & & & & & & \\
\hline Lags & 1 & 2 & 3 & 4 & 1 & 2 & 3 & 4 \\
\hline China \& India & 0.297 & 0.442 & 0.877 & 0.86 & 0.154 & $5.366^{*}$ & $8.262 * *$ & 7.715 \\
\hline
\end{tabular}

Notes: The *,**, and $* * *$ denote the significance at $10 \%, 5 \%$ and $1 \%$ levels, respectively.

Table 7 Linear Granger Causality

$\begin{array}{ll}\text { Null: Housing Return } & \text { Null: EPU growth } \\ \text { does not cause EPU growth } & \text { does not cause Housing Return }\end{array}$

\begin{tabular}{|c|c|c|c|c|c|c|c|c|}
\hline \multirow[b]{2}{*}{ Lags } & & \\
\hline & 1 & 2 & 3 & 4 & 1 & 2 & 3 & 4 \\
\hline China & 0.478 & 0.548 & 0.526 & 0.400 & $9.615 * * *$ & $7.781 * * *$ & $8.053 * * *$ & $3.861 * *$ \\
\hline India & 0.646 & 0.391 & 0.31 & 0.340 & 1.492 & 1.850 & 1.871 & 1.235 \\
\hline
\end{tabular}

Notes: The $*, * *$ and $* * *$ denote the significance at $10 \%, 5 \%$ and $1 \%$ levels, respectively.

Table 8 Panel Nonlinear Granger Causality

$\begin{array}{ll}\text { Null: Housing Return } & \text { Null: EPU growth } \\ \text { does not cause EPU growth } & \text { does not cause Housing Return }\end{array}$

\begin{tabular}{|c|c|c|c|c|c|c|c|c|}
\hline \multirow[b]{2}{*}{ Lags } & & \\
\hline & 1 & 2 & 3 & 4 & 1 & 2 & 3 & 4 \\
\hline China \& India & -0.482 & 0.282 & 0.683 & 0.738 & 1.087 & $1.932 * *$ & 0.293 & $2.354 * * *$ \\
\hline
\end{tabular}

Notes: The $*, * *$, and $* * *$ denote the significance at $10 \%, 5 \%$ and $1 \%$ levels, respectively. 
Table 9 Nonlinear Granger Causality

\begin{tabular}{|c|c|c|c|c|c|c|c|c|}
\hline \multirow[b]{2}{*}{ Lags } & \multicolumn{4}{|c|}{$\begin{array}{l}\text { Null: Housing Return } \\
\text { does not nonlinearly cause EPU } \\
\text { growth }\end{array}$} & \multicolumn{4}{|c|}{$\begin{array}{l}\text { Null: EPU growth } \\
\text { does not nonlinearly cause Housing } \\
\text { Return }\end{array}$} \\
\hline & 1 & 2 & 3 & 4 & 1 & 2 & 3 & 4 \\
\hline China & $1.467 *$ & 0.817 & 0.159 & 0.008 & $-3.074 * * *$ & $-2.191 * *$ & $-1.567^{*}$ & -1.105 \\
\hline India & $1.310^{*}$ & 0.578 & $1.442 *$ & $1.287 *$ & $-1.677 * *$ & $-1.972 * * *$ & $-1.382 *$ & -0.374 \\
\hline
\end{tabular}

Notes: The $* * *$, and $* * *$ denote the significance at $10 \%, 5 \%$ and $1 \%$ levels, respectively.

Table 10 Cross Linear Granger Causality

\begin{tabular}{|c|c|c|c|c|c|c|c|c|}
\hline \multirow[b]{2}{*}{ Lags } & \multicolumn{4}{|c|}{$\begin{array}{l}\text { Null: Housing Return from China } \\
\text { does not cause EPU growth in India }\end{array}$} & \multicolumn{4}{|c|}{$\begin{array}{l}\text { Null: EPU growth from India } \\
\text { does not cause Housing Return in China }\end{array}$} \\
\hline & 1 & 2 & 3 & 4 & 1 & 2 & 3 & 4 \\
\hline & 0.233 & 0.177 & 1.652 & 1.879 & $8.054 * * *$ & $5.973 * * *$ & $4.965^{* * * *}$ & $2.623^{*}$ \\
\hline & $\begin{array}{l}\text { Null: } \\
\text { does }\end{array}$ & $\begin{array}{l}\text { using } F \\
\text { cause } I\end{array}$ & $\begin{array}{l}n \text { from } \\
\text { growth }\end{array}$ & China & $\begin{array}{l}\text { Null: EP } \\
\text { does not }\end{array}$ & $\begin{array}{l}\text { growth fr } \\
\text { ause Hous }\end{array}$ & $\begin{array}{l}\text { om China } \\
\text { ng Retur }\end{array}$ & n India \\
\hline \multirow[t]{2}{*}{ Lags } & 1 & 2 & 3 & 4 & 1 & 2 & 3 & 4 \\
\hline & 2.763 & 1.347 & 0.779 & 0.620 & 1.021 & 0.359 & 0.359 & 0.384 \\
\hline
\end{tabular}

Notes: The $* * *$, and $* * *$ denote the significance at $10 \%, 5 \%$ and $1 \%$ levels, respectively.

Table 11 Cross Nonlinear Granger Causality

Null: Housing Return from China Null: EPU growth from India does not nonlinearly cause EPU growth in does not nonlinearly cause Housing Return India in China

\begin{tabular}{|c|c|c|c|c|c|c|c|c|}
\hline \multirow[b]{2}{*}{ Lags } & & & & & \\
\hline & 1 & 2 & 3 & 4 & 1 & 2 & 3 & 4 \\
\hline & 0.637 & -0.012 & -0.419 & 0.263 & -0.230 & 1.098 & -0.967 & 0.194 \\
\hline & $\begin{array}{l}\text { Null: } \\
\text { does } \\
\text { China }\end{array}$ & $\begin{array}{l}\text { using R } \\
\text { nonline }\end{array}$ & n from & growth in & $\begin{array}{l}\text { Null: I } \\
\text { does } n \\
\text { in Indi }\end{array}$ & $\begin{array}{l}\text { growt } \\
\text { online }\end{array}$ & $\begin{array}{l}\text { om Chi } \\
\text { cause I }\end{array}$ & ing Return \\
\hline \multirow[t]{2}{*}{ Lags } & 1 & 2 & 3 & 4 & 1 & 2 & 3 & 4 \\
\hline & 0.654 & -0.366 & -0.728 & -1.141 & 0.775 & 0.851 & 0.659 & 0.715 \\
\hline
\end{tabular}

Notes: The $*, * *$, and $* * *$ denote the significance at $10 \%, 5 \%$ and $1 \%$ levels, respectively. 


\section{APPENDIX:}

Table A1 Panel Linear Granger Causality

\begin{tabular}{|c|c|c|c|c|c|c|c|c|}
\hline \multirow[b]{2}{*}{ Lags } & \multicolumn{4}{|c|}{$\begin{array}{l}\text { Null: Housing Return } \\
\text { does not cause EPU growth }\end{array}$} & \multicolumn{4}{|c|}{$\begin{array}{l}\text { Null: EPU growth } \\
\text { does not cause Housing Return }\end{array}$} \\
\hline & 1 & 2 & 3 & 4 & 1 & 2 & 3 & 4 \\
\hline Before & 0.029264 & 1.753751 & 1.088056 & 2.469526 & 0.001125 & 1.280048 & 3.515400 & 3.632350 \\
\hline After & 0.100807 & 0.428833 & 0.475915 & 0.491588 & 0.264436 & 3.172557 & 6.012005 & $8.887597 *$ \\
\hline
\end{tabular}

Notes: The $*, * *$, and $* * *$ denote the significance at $10 \%, 5 \%$ and $1 \%$ levels, respectively.

Table A2 Linear Granger Causality

$\begin{array}{ll}\text { Null: Housing Return } & \text { Null: EPU growth } \\ \text { does not cause EPU growth } & \text { does not cause Housing Return }\end{array}$

\begin{tabular}{|c|c|c|c|c|c|c|c|c|}
\hline Lags & $\overline{1}$ & 2 & 3 & 4 & $\overline{1}$ & 2 & 3 & 4 \\
\hline \multicolumn{9}{|c|}{ Before } \\
\hline China & 0.030 & 0.062 & 0.216 & 1.751 & 0.111 & 1.692 & $6.633^{*}$ & $71.648 * * *$ \\
\hline India & 0.083 & 3.169 & 3.362714 & 1.499 & 0.083 & 3.464 & 1.993 & 2.730 \\
\hline \multicolumn{9}{|c|}{ After } \\
\hline China & 0.904 & 1.529 & 3.617 & 3.689 & $17.096 * * *$ & $26.316^{* * *}$ & $53.330 * * *$ & $42.997 * * *$ \\
\hline India & 0.441 & 0.729 & 0.678 & 0.624 & 1.990 & 2.120 & 4.241 & 5.172 \\
\hline
\end{tabular}

Notes: The $*, * *$, and $* * *$ denote the significance at $10 \%, 5 \%$ and $1 \%$ levels, respectively. 
Table A3 Panel Nonlinear Granger Causality

\begin{tabular}{|c|c|c|c|c|c|c|c|c|}
\hline \multirow[b]{2}{*}{ Lags } & \multicolumn{4}{|c|}{$\begin{array}{l}\text { Null: Housing Return } \\
\text { does not nonlinearly cause EPU growth }\end{array}$} & \multicolumn{4}{|c|}{$\begin{array}{l}\text { Null: EPU growth } \\
\text { does not nonlinearly cause Housing Return }\end{array}$} \\
\hline & $\overline{1}$ & 2 & 3 & 4 & $\overline{1}$ & 2 & 3 & 4 \\
\hline Before & 0.3820 & $\mathrm{NE}$ & $\mathrm{NE}$ & $\mathrm{NE}$ & -0.88768 & $\mathrm{NE}$ & $\mathrm{NE}$ & $\mathrm{NE}$ \\
\hline After & -0.7449 & -0.924 & $2.5618 * * *$ & $\mathrm{NE}$ & $-1.5943^{*}$ & $-1.45158 *$ & $-2.9649 * * *$ & $\mathrm{NE}$ \\
\hline
\end{tabular}

Notes: The ${ }^{*}, * *$, and $* * *$ denote the significance at $10 \%, 5 \%$ and $1 \%$ levels, respectively. NE indicates non-evaluable as there are insufficient observations for test statistic constructing.

Table A4 Nonlinear Granger Causality

\begin{tabular}{|c|c|c|c|c|c|c|c|c|}
\hline \multirow[b]{2}{*}{ Lags } & \multicolumn{4}{|c|}{$\begin{array}{l}\text { Null: Housing Return } \\
\text { does not nonlinearly cause EPU }\end{array}$} & \multicolumn{4}{|c|}{$\begin{array}{l}\text { Null: EPU growth } \\
\text { does not nonlinearly cause Housing Return }\end{array}$} \\
\hline & 1 & 2 & 3 & 4 & 1 & 2 & 3 & 4 \\
\hline \multicolumn{9}{|c|}{ Before } \\
\hline China & 0.1690 & $\mathrm{NE}$ & $\mathrm{NE}$ & $\mathrm{NE}$ & -0.07765 & $\mathrm{NE}$ & $\mathrm{NE}$ & $\mathrm{NE}$ \\
\hline India & 0.12799 & $\mathrm{NE}$ & $\mathrm{NE}$ & $\mathrm{NE}$ & 1.2603 & $\mathrm{NE}$ & $\mathrm{NE}$ & $\mathrm{NE}$ \\
\hline \multicolumn{9}{|c|}{ After } \\
\hline China & -0.8232 & -0.68186 & 0.0280 & $\mathrm{NE}$ & $-1.5024^{*}$ & $-1.8710^{* *}$ & $-1.98239 * *$ & $\mathrm{NE}$ \\
\hline India & $-1.6072 *$ & -0.6550 & 0.9466 & $\mathrm{NE}$ & $1.4137 *$ & -0.0936 & -0.3671 & $\mathrm{NE}$ \\
\hline
\end{tabular}

Notes: The $* * *$, and $* * *$ denote the significance at $10 \%, 5 \%$ and $1 \%$ levels, respectively. NE indicates non-evaluable as there are insufficient observations for test statistic constructing. 